\title{
Methylene blue decolorizing bacteria isolated from water sewage in Yogyakarta, Indonesia
}

\author{
MICHELLE, RACHEL ARVY NABASA SIREGAR, ASTIA SANJAYA, JAP LUCY, REINHARD PINONTOAN \\ Department of Biology, Faculty of Science and Technology, Universitas Pelita Harapan. Jl. M.H. Thamrin Boulevard 1100, Lippo Karawaci, \\ Tangerang 15811, Banten, Indonesia. Tel./Fax.+62-21-5460901, `email: reinhard.pinontoan@uph.edu
}

Manuscript received: 11 December 2019. Revision accepted: 20 February 2020.

\begin{abstract}
Michelle, Siregar RAN, Sanjaya A, Jap L, Pinontoan R. 2020. Methylene blue decolorizing bacteria isolated from water sewage in Yogyakarta, Indonesia. Biodiversitas 21: 1136-1141. The textile industry contributes to water pollution issues all over the world. One of the most commonly applied cationic dye in the textile industry is methylene blue. This study aimed to isolate bacteria with the potential to decolorize methylene blue from dye contaminated sewage water located in Kulon Progo District, Yogyakarta, where several textile industries within the proximity, are located. Characterizations of bacterial candidates were done morphologically and biochemically. Molecular identification was conducted by 16S rRNA sequencing. The ability of isolates to decolorize methylene blue was observed by the reduction of methylene blue's maximum absorption at the wavelength of $665 \mathrm{~nm}$. The results showed that isolates were identified as Comamonas aquatica and Ralstonia mannitolilytica. C. aquatica PMB-1 and $R$. mannitolilytica PMB-2 isolates were able to decolorize methylene blue with decolorization percentage of $67.9 \%$ and $60.3 \%$, respectively when incubated for 96 hours at $37^{\circ} \mathrm{C}$. These findings present information on the capability of the genus Ralstonia and Comamonas to decolorize methylene blue cationic dye.
\end{abstract}

Keywords: Comamonas aquatica, decolorization, methylene blue, Ralstonia mannitolilytica, Yogyakarta

\section{INTRODUCTION}

The textile industries are known as the major source of water pollution all over the world (Ito et al. 2016). Textile industrial wastes contain dyes which are often disposed into the nature aggravating pollution problems due to their toxicity. Most of these dyes are not readily degradable under natural conditions and resistant to conventional wastewater treatment systems (Yaseen and Scholz 2019). The emitted textile effluents impose substantial adverse effects on water quality, soil fertility, and marine life, causing ecosystem disruptions (Croce et al. 2017). For those living adjacent to contaminated riverbanks or other water sources, short-term exposure to textile dyes can lead to skin and eye irritation as well as allergic reactions, while continued exposure could even lead to cancer due to mutagenicity and carcinogenicity of these dyes (Lellis et al. 2019).

One of the most common cationic dyes that are often applied in textile, leather, paper, plastic, and craft industries is methylene blue (Rafatullah et al. 2010). Methylene blue contaminated waste was reported to impose health risks such as nausea, dizziness, and chest pain to the exposed population and reduce the biodiversity of the affected ecosystems (Zhou et al. 2019). Many technologies have been employed to eliminate the contamination of methylene blue in the environment. Recently, physicochemical approaches, including photocatalysis, physiochemical adsorption, and non-thermal plasma technology, have garnered popularity due to its high efficiency and degradation percentage (Das et al. 2019; Myung et al. 2019; Wu et al. 2019). However, high complexity, low economic feasibility, and disposal problems by some of these methods hinder their broad application, especially in a developing country (Zhou et al. 2019). Wastewater treatment by biological approach offers a more cost-efficient and sustainable alternative solution is contrary to the huge expenditure specified by the physicochemical approach. In the biological method, microbes were utilized for the degradation of the toxic textile dyes. Microorganisms that have been studied and demonstrated effective removal of methylene blue include Stenotrophomonas maltophilia and Pseudomonas aeruginosa isolated from contaminated soil, Sphingomonas paucimobilis isolated from the drainage system, and Bacillus thuringiensis (Noraini et al. 2012; Chen et al. 2015; Eslami et al. 2017; Kilany 2017).

Although Indonesia owns high biological diversity, there are only limited bacteria species being reported as a bioremediation agent of a textile dye in contaminated water. Therefore, this study aimed to isolate potential methylene blue-decolorizing bacteria from dye contaminated sewage water located in Kulon Progo District, Yogyakarta, where several textile industries are located within the proximity.

\section{MATERIALS AND METHODS}

\section{Study area}

Kulon Progo is one of the regencies located in the Yogyakarta Special Region, Indonesia, named after its location from the Progo River. Being one area that 
specialized in the textile industry businesses, the sewers in this area receive a heavy load of textile dyes-contaminated wastewater from the surrounding home textile industries. To isolate bacteria with the ability to decolorize methylene blue, sewage water from a large sewer at Ngentakrejo, Kulon Progo, Special Region of Yogyakarta, Indonesia, was taken as a sample. The sampling location was presented in Figure 1.

\section{Procedures}

Isolation of bacteria from Yogyakarta sewage water

Collected water samples were diluted $\left(10^{-1}\right)$ with sterile water and plated $(200 \mu \mathrm{l})$ on GYP (glucose yeast peptone) agar ( $1 \%$ glucose, $0.5 \%$ yeast, $0.5 \%$ peptone, $2 \%$ agar) supplemented with $50 \mathrm{ppm}$ methylene blue (Merck, Germany) and incubated at $37^{\circ} \mathrm{C}$ for 96 hours. Bacteria isolates with clear zones around their colonies were selected, purified, and maintained on GYP agar supplemented with $50 \mathrm{ppm}$ methylene blue for further analysis.

Characterization of bacteria from Yogyakarta sewage water

Cell and colony morphology were observed to characterize potential bacteria. Isolated candidates for methylene blue decolorizer were streak-plated on GYP agar supplemented with $50 \mathrm{ppm}$ methylene blue, incubated at $37^{\circ} \mathrm{C}$ for 96 hours. Cell appearances observed through Gram-staining examined using a light microscope with a $1000 x$ total magnification. Colony appearances include shape, color, margin, and elevations. Biochemical characterization through Voges-Proskauer (VP) assay, indole assay, catalase assay, and starch hydrolysis were conducted as described by Bergey's Manual of Systematic Bacteriology (Guerrero 2001).

\section{Molecular identification of bacterial isolates}

The 16S rRNA gene was amplified and sequenced to identify bacteria isolates. Pure isolates were cultured on GYP broth media incubated at $37^{\circ} \mathrm{C}$ overnight. Three $\mathrm{ml}$ of the broth culture of each isolate was centrifuged at 16,000 $\mathrm{x} g$ for $3 \mathrm{~min}$ and the pellet was used for DNA extraction. The extraction of bacterial genomic DNA was conducted using the Wizard $^{\circledR}$ Genomic DNA Purification Kit according to manufacturer instructions (Promega, USA).

The quality and yield of extracted genomic DNA were assessed by a UV/Vis spectrophotometer (BioDrop, UK) and used as a template for $16 \mathrm{~S}$ rRNA gene amplification by PCR reactions. All PCR reactions were conducted by employing universal primers 27F (5'-AGA GTT TGA TCM TGG CTC AG-3') and 1492R (5'-GGT TAC CTT GTT ACG ACT T-3') to amplify $16 \mathrm{~S}$ rRNA gene using isolated genomic DNA from each isolate. KAPA $\mathrm{HiFi}^{\mathrm{TM}}$ Taq Polymerase, dNTP and fidelity buffer (Kapa Biosystems, USA) were mixed in $50 \mu \mathrm{L}$ total volume per reaction under PCR conditions as follow, initial denaturation at $95^{\circ} \mathrm{C}$ for $3 \mathrm{~min}$, twenty-five cycles of amplification consisted of denaturation at $98^{\circ} \mathrm{C}$ for $20 \mathrm{sec}$, annealing at $55^{\circ} \mathrm{C}$ for $15 \mathrm{sec}$ and extension at $72^{\circ} \mathrm{C}$ for 60 sec. A final extension phase was performed at $72^{\circ} \mathrm{C}$ for $2 \mathrm{~min}$.

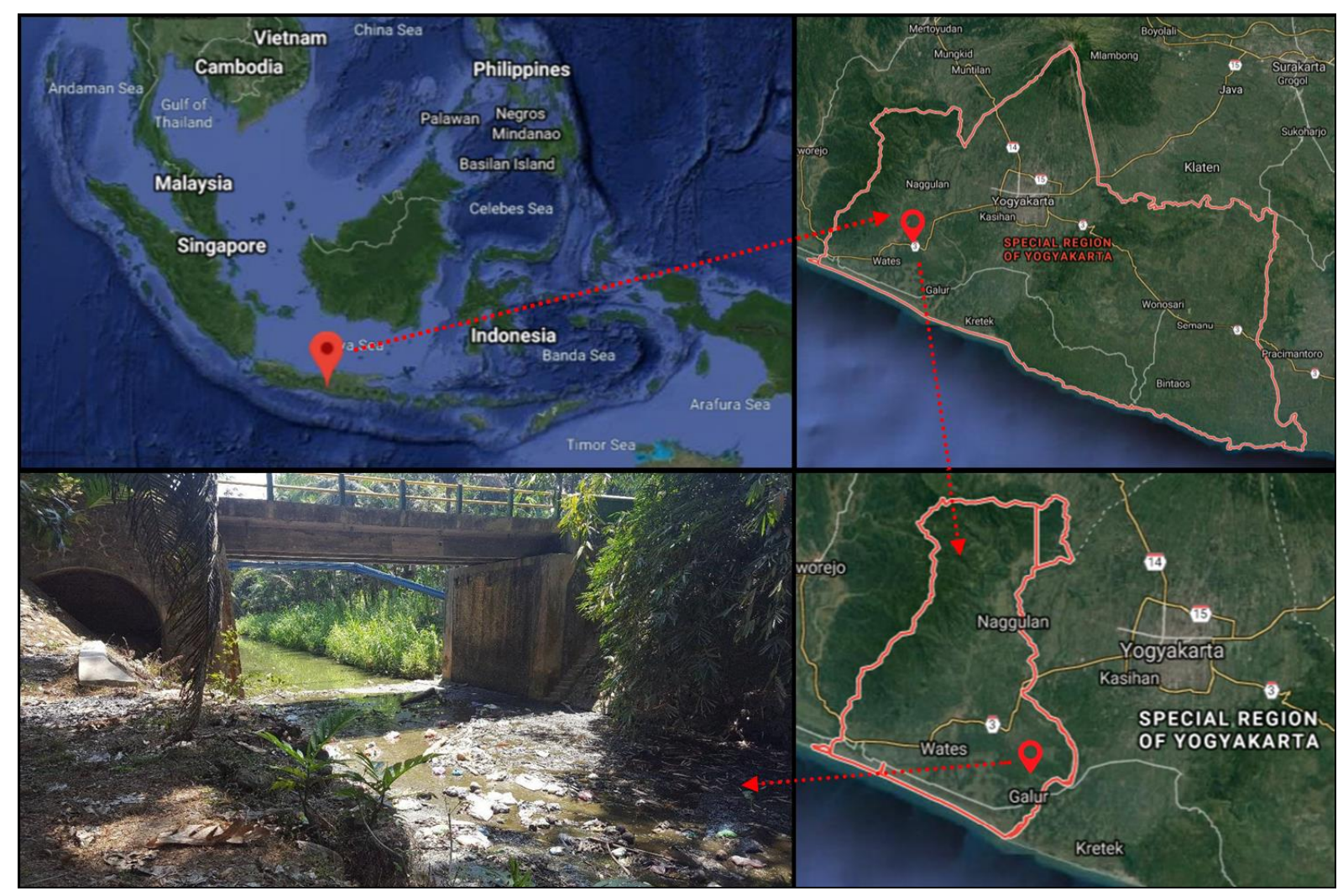


Figure 1. Sewerage in Kulon Progo District, Special Region of Yogyakarta, Indonesia as a water sampling location for bacterial isolation (geographic coordinate: -7.907293,110.264097). Source: Google Inc, 2019

Table 1. Cell, morphological colony and biochemical characterization of PMB-1, PMB-2 and PMB-3 isolates

\begin{tabular}{|c|c|c|c|c|}
\hline \multirow{2}{*}{\multicolumn{2}{|c|}{ Characteristics }} & \multicolumn{3}{|c|}{ Isolates } \\
\hline & & PMB-1 & PMB-2 & PMB-3 \\
\hline \multirow[t]{2}{*}{ Cellular morphology } & Shape & Rod & Rod & Rod \\
\hline & Gram staining & Negative & Negative & Negative \\
\hline \multirow[t]{4}{*}{ Colony morphology } & Shape & Circular & Circular & Circular \\
\hline & Color & Blue & Yellow & Blue \\
\hline & Margin & Lobate & Lobate & Lobate \\
\hline & Elevation & Flat & Flat & Flat \\
\hline \multirow[t]{4}{*}{ Biochemical characterization } & Voges-Proskauer (VP) & - & - & - \\
\hline & Indole & - & - & - \\
\hline & Catalase & - & - & - \\
\hline & Starch Hydrolysis & - & - & - \\
\hline
\end{tabular}

Note: (-) represents negative results

PCR products were visualized on a $0.8 \%$ agarose gel stained with ethidium bromide under UV light to confirm the presence of an approximate $1.4 \mathrm{kbp}$ band. The $16 \mathrm{~S}$ rRNA PCR products were sent to First BASE Laboratories Pte. Ltd., Malaysia, for DNA sequencing.

\section{Measurement of decolorization activity}

Bacteria isolates were inoculated in GYP broth media supplemented with $50 \mathrm{ppm}$ methylene blue and statically incubated at $37^{\circ} \mathrm{C}$ for 96 hours under aerobic conditions. Dye degradation was indicated by the reduction of the intensity of the blue-colored media at the end of the incubation period.

The sample was centrifuged at 9,600 x $\mathrm{g}$ for 10 minutes to yield pellets of bacterial cells. The decolorization activity was measured in terms of decolorization percentage of supernatant by measuring color intensity reduction using UV/Vis spectrophotometer (BioDrop, UK) with a wavelength range of $400-800 \mathrm{~nm}$. The decrease in the absorbance at wavelength of $665 \mathrm{~nm}$ indicated methylene blue decolorization. Percentage of decolorization was measured using the equation as follow:

Percentage of decolorization $(\%)=(\mathrm{A}-\mathrm{B}) / \mathrm{A} \times 100 \%$

Where,

A : initial absorbance

B : sample absorbance after treatment

\section{Data analysis}

The 16S rRNA partial sequences of selected isolates were processed using Sequence Scanner 2 (Applied Biosystems, USA) and BioEdit software, and then compared to previously deposited 16S rRNA gene sequences from NCBI GenBank database to identify the bacteria isolate using the BLAST algorithm (http://www.ncbi.nlm.nih.gov/BLAST/Blast.cgi). The nucleotide sequences of the 16S rRNA gene of the PMB-1 and PMB-2 isolates have been deposited in Genbank under the accession number MH890458 and MH890459, respectively. The phylogenetic tree was constructed using the maximum likelihood, and genetic distances were generated using the Tamura-Nei model with a 1000 bootstrap value, after alignment through MUSCLE, as implemented in MEGA.X software (Pavlopoulos et al.
2010). Statistical analysis of the decolorization activity was done using one-way ANOVA with posthoc Tukey HSD test in GraphPad Prism software to determine the statistical differences between treated samples and control.

\section{RESULTS AND DISCUSSION}

\section{Isolation and identification of methylene blue decolorizing bacteria}

Three isolates, PMB-1, PMB-2, and PMB-3, collected from sewage water in Kulon Progo-Yogyakarta, showed the ability to decolorize methylene blue in agar media. Cell and the morphological colony, as well as biochemical characteristics of PMB-1 and PMB-3, were indistinguishable when grown on methylene blue supplemented media, indicating that both isolates were most likely to be identical. PMB-2 isolate has a yellow colony which demonstrated different colony color from PMB-1 and PMB-3 (Table 1). The ability of PMB-1 and PMB-3 to accumulate methylene blue inside the cell might contribute to the blue color appearance of their colonies. Based on the characterization of isolates that refer to Bergey's manual showed that PMB-1, PMB-2, and PMB-3 isolates belong to the genus of Pseudomonas. (Guerrero 2001).

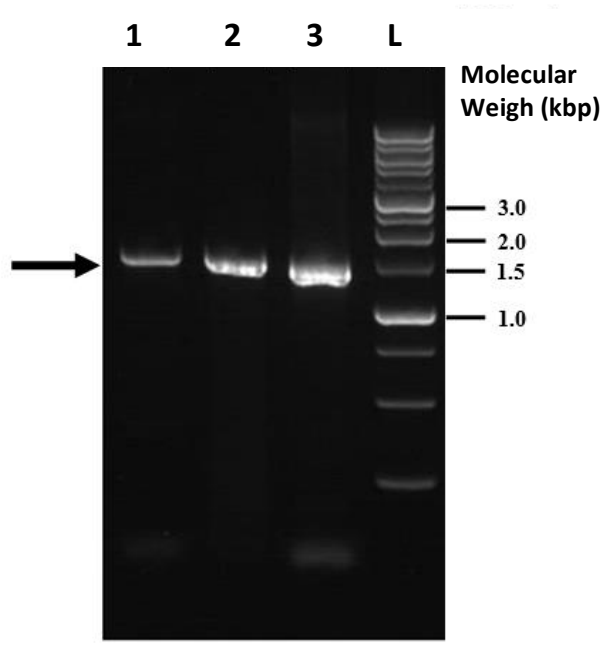


Figure 2. The $16 \mathrm{~S}$ rRNA genes amplification of PMB-1, PMB-2, and PMB-3. Agarose gel electrophoresis was run using $0.8 \%$ agarose gel for 20 minutes at 100V. Line 1-3: PMB-1, PMB-2, PMB-3; L:
$1 \mathrm{~kb}$ DNA ladder (Geneaid, Taiwan). The arrow indicates PCR products of the three isolates.

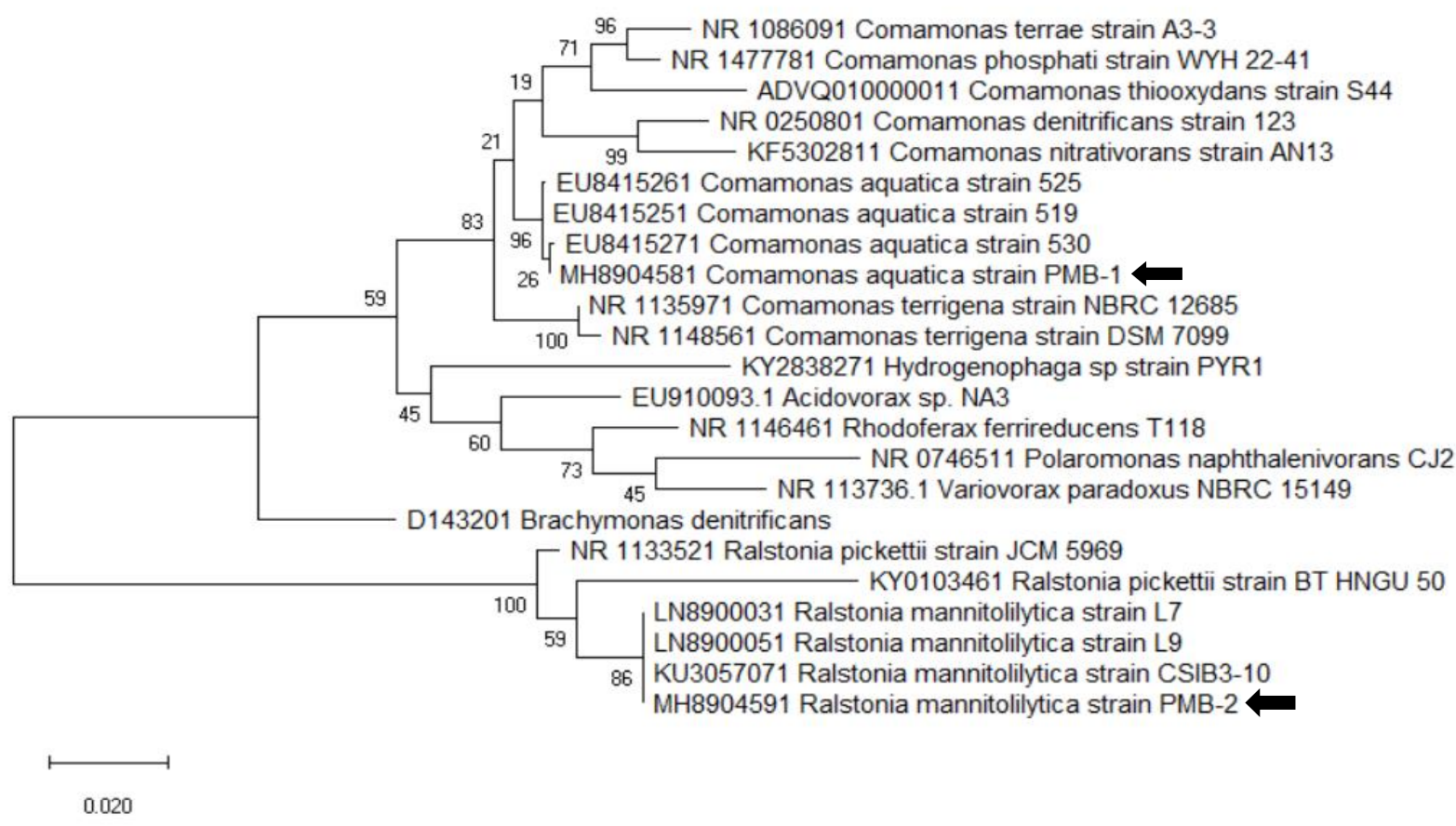

Figure 3. Phylogenetic tree of Comamonas sp. and Ralstonia sp. constructed by MEGA.X software through maximum likelihood tree derived from a distance matrix of $16 \mathrm{~S}$ rDNA sequences. Arrows indicate $C$. aquatica PMB-1 and $R$. mannitolilytica PMB-2

Molecular identification was conducted to verify the identity of three bacterial isolates that capable of decolorizing methylene blue. The 16S rRNA genes of the three bacterial isolates were successfully amplified through PCR, as indicated by the presence of a single DNA band of approximately $1.4 \mathrm{kbp}$ on agarose gel electrophoresis (Figure 2).

Basic Local Alignment Search Tool (BLAST) showed that PMB-1 and PMB-3 isolates were $100 \%$ identical with Comamonas aquatica; however, only PMB-1 with 1,378 bp nucleotide length was selected for further analysis in this study. The genus Comamonas was previously classified within the Pseudomonas genus of $\gamma$ proteobacteria and belonged to Comamonadaceae lineage in the group of $\beta$-proteobacteria. The genus Comamonas has been extensively studied for various bioremediations application and was reported to be a natural pollutant degrading microbe. Both of $C$. nitrativorans and $C$. denitrificans isolated from denitrification of activated sludge were reported to convert nitrate to nitrogen (Xing et al. 2010; Maintinguer et al. 2013), while C.tertosteroni can reduce heavy metals selenite (Zheng et al. 2014). C. terrae strain A3-3 isolated from tannery wastes and agricultural soils have shown to potentially oxidize arsenite to arsenate (Chitpirom et al. 2009). C. jiangduensis SZZ 10 has the potential to degrade the diuron herbicide (Hanapiah et al. 2018). Despite the genus Comamonas involvement in several bioremediations, there is currently no study on the ability of $C$. aquatica to decolorize dyes.
BLAST sequence analysis for the 16S rRNA gene showed that PMB-2 with 1,398 bp nucleotide length was $100 \%$ identical to Ralstonia mannitolilytica. Isolate PMB-2 was thought to be the genus Pseudomonas based on the biochemical characteristics (Ryan et al. 2011). Ralstonia mannitolilytica was previously identified as Pseudomonas thomasii, which is commonly found in soil and water and mostly present in industrial and polluted biotopes, and metallurgic wastes (Lucarelli et al. 2017). $R$. mannitolilytica was previously reported as cadmium bioremediating bacteria (Ojuederie and Babalola 2017).

The phylogenetic tree of $\beta$-proteobacteria species was constructed by MEGA.X based on 16S rRNA gene sequences (Figure 3) showed that PMB-1 belongs to the clade of $C$. aquatica, whereas isolate PMB-2 belongs to the clade of $R$. mannitolilytica. Other definitive genera in the $\beta$-proteobacteria include Acidovorax, Brachymonas, Hydrogenophaga, Polaromonas, Rhodoferax, Variovorax, and Xylophilus (Willems 2014). The group of $\beta$ proteobacteria was described as an efficient bioremediating agent. Acidovorax sp. is capable effectively in the bioremediation of soil contaminated with polycyclic aromatic hydrocarbons (Singleton et al. 2009). Brachymonas denitrificans has activity as nitrogen-removal bacteria (Zhao et al. 2017). Hydrogenophaga sp. isolated from polycyclic aromatic hydrocarbon-contaminated soil can degrade pyrene under iron-reducing anaerobic conditions (Yan et al. 2017). Rhodoferax ferrireducens isolated from subsurface sediments showed the activity as 
microbial fuel cells for electricity generation (Risso et al. 2009). Similar to Acidovorax sp., Variovorax sp. isolated from a coal tar-contaminated aquifer possess putative aromatic ring hydroxylation dioxygenase enzymes that enable bacteria to degrade benzene (Posman et al. 2017). However, there is no information regarding the ability of Xylophilus to facilitate bioremediation.

\section{Decolorization activity of isolates PMB-1 and PMB-2}

Decolorization activity was done by measuring the absorbance of culture supernatants at the maximum wavelength of methylene blue absorption, which is $665 \mathrm{~nm}$ (Briggs et al. 2018) by spectrophotometer. The absorbance of the culture supernatant of $C$. aquatica PMB-1 and $R$. mannitolilytica PMB-2 compared to GYP broth as a control showed a similar reduction of the peak at a wavelength of $665 \mathrm{~nm}$ with decolorization percentage \pm SEM (standard error of the mean) of $67.9 \pm 9.94 \%$ and $60.3 \pm 12.86 \%$, respectively (Figure 4). The results showed a significant reduction $(\mathrm{P} \leq 0.05)$ in the absorbance of methylene blue in the treated samples; it showed the ability of both isolated bacteria to reduce the concentration of methylene blue in the sample. Statistical analysis showed that there was no significant difference between the absorbance value of PMB-1 and PMB-2 treated samples at $665 \mathrm{~nm}(\mathrm{P}>0.05)$.

The exact mechanism of methylene blue decolorization by $C$. aquatica PMB-1 and $R$. mannitolilytica PMB-2 still needs to be studied. However, previous studies on methylene blue-decolorizing bacteria showed that methylene blue removal from aqueous solution mainly achieved by two primary mechanisms, i.e.,: biosorption and biodegradation (Noraini et al. 2012; Eslami et al. 2017; Habibi and Mehrabi 2017; Kilany 2017). Biosorption of cationic dyes which was observed not only on bacterial surface but also on other biomass including fungi (Maas et al. 2018), algae (Guarin et al. 2018) and water plant (Pinontoan et al. 2019), occurs through interaction between negatively-charged phosphate groups on the surface of the biomass and positively-charged dyes. Electrostatic attraction keeps the dyes bound to the biomass, which indicated by a noticeable change of the biomass color (Habibi and Mehrabi 2017; Kilany 2017). Biodegradation occurs because of the presence of enzymes produced by the living cell, which can break down directly the toxic dyes. Many bacteria employ both mechanisms in the decolorization process, in which cationic dyes are first adsorbed to their surface and enzymatically degraded in subsequent reactions (Chen et al. 2015).

The previous study showed that other Proteobacteria, namely Stenotrophomonas maltophilia and Pseudomonas aeruginosa isolated from contaminated soil, were able to decolorize methylene blue effectively through biosorption and biodegradation process (Eslami et al. 2017; Kilany 2017). Sphingomonas paucimobilis, isolated from a closed drainage system in Malaysia, can break down methylene blue enzymatically under aerobic conditions (Noraini et al. 2012). Recently, different species of Ralstonia, i.e., $R$. eutropha, can adsorb and degrade methylene blue in aqueous solution under aerobic conditions, with biodegradation as its predominant mechanism (Habibi and Mehrabi 2017).

In this study, the culture of $C$. aquatica PMB-1 grown in methylene blue-supplemented medium had blue-colored colonies, suggesting that this bacterium might be able to absorb the dye onto the surface of its cell. However, further experiments are needed to determine the extent of methylene blue biosorption and biodegradation capability of $C$. aquatica PMB-1 and $R$. mannitolilytica PMB-2.

So far, there is no previous report on $C$. aqutica and $R$. mannitolilytica as decolorizer of cationic dyes such as methylene blue. The findings in this study provide additional information on the capability of the Ralstonia and Comamonas genera to break down cationic dyes. However, toxicity assay and further evaluation of the decolorization potential need to be carried out to optimize the application of both isolates as bioremediation agents.

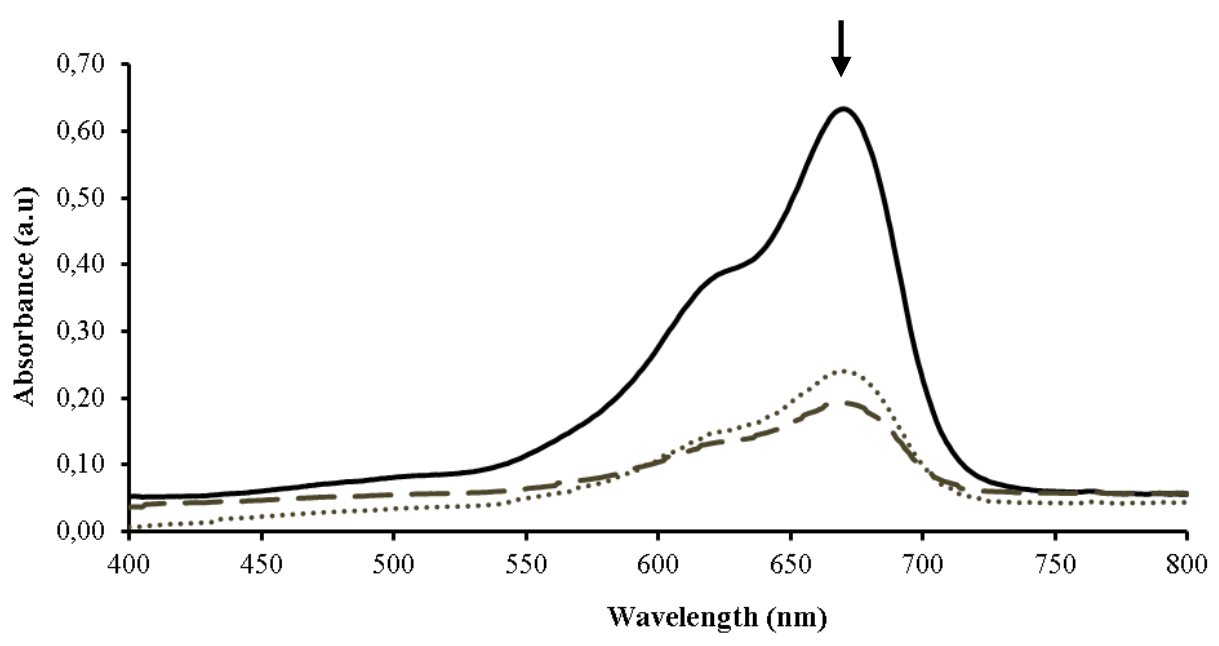

Figure 4. The decolorizing activity of $C$. aquatica PMB-1 and $R$. mannitolilytica PMB-2. The isolates were incubated in 50 ppm methylene blue supplemented media incubated at $37^{\circ} \mathrm{C}$ for 96 hours. The profiles were measured using a UV-Vis spectrophotometer. 
Values are expressed as the mean $(n=3)$. Solid line ( ): GYP + 50 ppm methylene blue as control; broken line ( - - - - ): GYP + 50 ppm methylene blue $+C$. aquatica PMB-1; Dotted line (.....): GYP +50 ppm methylene blue + R. mannitolilytica PMB-2. The arrow indicates the adsorption peak of methylene blue at $665 \mathrm{~nm}$.

\section{ACKNOWLEDGEMENTS}

The authors acknowledge financial support in part from The Indonesian Ministry of Education, Directorate General of Higher Education (DIKTI) (0419/K3/KM/2017) and Research and Community Development, Universitas Pelita Harapan.

\section{REFERENCES}

Briggs T, Blunn G, Hislop S, Ramalhete R, Bagley C, McKenna D, Coathup M. 2018. Antimicrobial photodynamic therapy-a promising treatment for prosthetic joint infections. Lasers Med Sci 33: 523-532.

Chen Z, Chen H, Pan X, Lin Z, Guan X. 2015. Investigation of methylene blue biosorption and biodegradation by Bacillus thuringiensis 016 . Water Air Soil Pollut 226: 1-8

Chitpirom K, Akaracharanya A, Tanasupawat S, Leepipatpibooim N, Kim KW. 2009. Isolation and characterization of arsenic resistant bacteria from tannery wastes and agricultural soils in Thailand. Ann Microbiol 59: 649-656

Croce R, Cina F, Lombardo A, Crispeyn G, Cappelli CI, Vian M, Maiorana S, Benfenati E, Baderna D. 2017. Aquatic toxicity of several textile dye formulations: Acute and chronic assays with Daphnia magna and Raphidocelis subcapitata. Ecotoxicol Environ Saf. 144: 79-87.

Das GS, Shim JP, Bhatnagar A, Tripathi KM, Kim TY. 2019. Biomass derived carbon quantum dots for visible-light-induced photocatalysi and label-free detection of Fe (III) and ascorbic acid. Sci Rep 9: 1-9.

Eslami H, Sedighi KS, Salehi F, Khosravi R, Fallahzadeh RA, Peirovi R, Sadeghi S. 2017. Biodegradation of methylene blue from aqueous solution by bacteria isolated from contaminated soil. J Adv Environ Health Res 5: 10-15.

Google Inc. 2019. Google Maps: Ngentakrejo, Kulon Progo, Special Region Yogyakarta, Indonesia. https://www.google.com/maps/@7.907293,110.264097,3a,75y,114.4 $8 \mathrm{~h}, 86.49 \mathrm{t} /$ data $=! 3 \mathrm{~m} 6$ !1 $1 \mathrm{e} 13 \mathrm{~m} 4$ ! 1 smifU316 cJqbCjA4sUPOJxw!2e0!7i 13312 ! 8i6656 [November 2019]

Guarin JR, Moreno-Pirajan JC, Giraldo L. 2018. Kinetic study of the bioadsorption of methylene blue on the surface of the biomass obtained from the algae $D$. antarctica. J Chem 2018: 1-12.

Guerrero R. 2001. Bergey's manuals and the classification of prokaryotes. Int Microbiol 4: 103-109.

Habibi A, Mehrabi Z. 2017. Aerobic degradation of methylene blue from colored effluents by Ralstonia eutropha. Pollution 3: 363-375.

Hanapiah M, Zulkifli SZ, Mustafa M, Mohamat-Yusuff F, Ismail A. 2018 Isolation, characterization, and identification of potential Diurondegrading bacteria from surface sediments of Port Klang, Malaysia. Mar Pollut Bull 127: 453-457.

Ito T, Adachi Y, Yamanashi Y, Shimada Y. 2016. Long-term natural remediation process in textile dye-polluted river sediment driven by bacterial community changes. Water Res 100: 458-465.

Kilany M. 2017. Isolation, screening and molecular identification of novel bacterial strain removing methylene blue from water solutions. Appl Water Sci 7: 4091-4098.

Lellis B, Favaro-Polonio CZ, Pamphile JA, Polonio JC. 2019. Effects of textile dyes on health and the environment and bioremediation potential of living organisms. Biotechnol Res Innov 50: 1-16.

Lucarelli C, Di Domenico EG, Toma L, Bracco D, Prignano G, Fortunati M, Pelagalli L, Ensoli F, Pezzotti P, García-Fernández A, Pantosti A Ingrosso L. 2017. Ralstonia mannitolilytica infections in an oncologic day ward: Description of a cluster among high-risk patients. Antimicrob. Resist Infect Control 6: 1-7.

Maas ASVD, da Silva NJR, da Costa ASV, Barros AR, Bomfeti CA 2018. The degradation of methylene blue dye by the strains of
Pleurotus sp. with potential applications in bioremediation processes. Rev Ambient Agua 13: 1-10.

Maintinguer SI, Sakamoto IK, Adorno MAT, Varesche MBA. 2013. Evaluation of the microbial diversity of denitrifying bacteria in batch reactor. Braz J Chem Eng 30: 457-465.

Myung Y, Jung SJ, Tung TT, Tripathi KM, Kim TY. 2019. Graphenebased aerogels derived from biomass for energy storage and environmental remediation. ACS Sustain Chem Eng 7: 3772-3782.

Noraini CHC, Morad N, Norli I, Teng TT, Ogugbue CJ. 2012. Methylene blue degradation by Sphingomonas paucimobilis under aerobic conditions. Water Air Soil Pollut 223: 5131-5142.

Ojuederie OB, Babalola OO. 2017. Microbial and plant-assisted bioremediation of heavy metal polluted environments: A review. Int. J Environ Res Public Health 14: 1-26.

Pavlopoulos GA, Soldatos TG, Barbosa-Silva A, Schneider R. 2010. A reference guide for tree analysis and visualization. BioData Min 3: 1 10

Pinontoan R, Supandi MT, Andhika J, Sutanto MI, Victor H. 2019. Removal of malachite green toxicity using water hyacinth (Eichhornia crassipes) biomass. IOP Conf Ser: Earth Environ Sci 346: 1-8.

Posman KM, DeRito CM, Madsen EL. 2017. Benzene degradation by a Variovorax species within a coal tar-contaminated groundwater microbial community. Appl Environ Microbiol 83: 1-13.

Rafatullah M, Sulaiman O, Hashim R, Ahmad A. 2010. Adsorption of methylene blue on low-cost adsorbents: A review. J Hazard Mater 177: 70-80.

Risso C, Sun J, Zhuang K, Mahadevan R, DeBoy R, Ismail W, Shrivastava S, Huot H, Kothari S, Daugherty S, Bui O, Schilling CH, Lovley DR, Methé BA. 2009. Genome-scale comparison and constraint-based metabolic reconstruction of the facultative anaerobic Fe (III)-reducer Rhodoferax ferrireducens. BMC Genomics 10: 447447.

Ryan MP, Pembroke JT, Adley CC. 2011. Genotypic and phenotypic diversity of Ralstonia pickettii and Ralstonia insidiosa isolates from clinical and environmental sources including high-purity water. Diversity in Ralstonia pickettii. BMC Microbiol 11: 194-205.

Singleton DR, Guzmán RL, Aitken MD. 2009. Characterization of a polycyclic aromatic hydrocarbon degradation gene cluster in a phenanthrene-degrading Acidovorax strain. Appl Environ Microbiol 75: 2613-2620.

Wu L, Xie Q, Lv Y, Zhang Z, Wu Z, Liang X, Lu M, Nie Y. 2019. Degradation of methylene blue by dielectric barrier discharge plasma coupled with activated carbon-supported on polyurethane foam. RSC Adv. 9: 25967-25975.

Willems A. 2014. The Prokaryotes: Alphaproteobacteria and Betaproteobacteria. Springer Berlin Heidelberg, Berlin, Heidelberg.

Xing D, Cheng S, Logan BE, Regan JM. 2010. Isolation of the exoelectrogenic denitrifying bacterium Comamonas denitrificans based on dilution to extinction. Appl Microbiol Biotechnol 85: 15751587.

Yan Z, Zhang Y, Wu H, Yang M, Zhang H, Hao Z, Jiang H. 2017. Isolation and characterization of a bacterial strain Hydrogenophaga sp. pyr1 for anaerobic pyrene and benzo[a]pyrene biodegradation. RSC Adv 7: 46690-46698.

Yaseen DA, Scholz M. 2019. Textile dye wastewater characteristics and constituents of synthetic effluents: a critical review. Intl J Environ 16: 1193-1226.

Zhao J, Wu J, Li X, Wang S, Hu B, Ding X. 2017. The denitrification characteristics and microbial community in the cathode of an MFC with aerobic denitrification at high temperatures. Front Microbiol 8: $1-11$.

Zheng S, Su J, Wang L, Yao R, Wang D, Deng Y, Wang R, Wang G, Rensing C. 2014. Selenite reduction by the obligate aerobic bacterium Comamonas testosteroni $\mathrm{s} 44$ isolated from a metal-contaminated soil. BMC Microbiol 14: 204. DOI: 10.1186/s12866-014-0204-8.

Zhou S, Du Z, Li X, Zhang Y, He Y, Zhang Y. 2019. Degradation of methylene blue by natural manganese oxides: kinetics and transformation products. R Soc Open Sci 6: 190351-190363. 